\title{
Dependent Arising and Interdependence
}

\author{
Bhikkhu Anālayo ${ }^{1}$ (D) \\ Accepted: 27 October 2020 / Published online: 25 November 2020 \\ (C) OThe Author(s) 2020, corrected publication 2021
}

\begin{abstract}
The Buddhist teaching on dependent arising (or dependent origination) concerns specific conditions whose presence is indispensable for something to come into existence. In the early stages of Buddhist history, the overarching concern of this doctrine was to identify the specific causes responsible for the human predicament, with a view to bringing about their cessation so as to become liberated. In later times, Buddhist exegesis developed various perspectives on causality, where in Huayan philosophy in particular the notion of interconnectedness or interdependence arose, according to which all phenomena relate to each other in one way or another. Despite its traction in the contemporary setting, this notion needs to be recognized as a later development that is by no means identical with the basic Buddhist teaching on dependent arising.
\end{abstract}

Keywords Conditionality · Dependent arising · Dependent origination · Interconnectedness scale $\cdot$ Interdependence · Pațiccasamuppāda $\cdot$ Pratītyasamutpāda $\cdot$ Specific conditionality

Progress in the understanding of mindfulness in its various applications can benefit greatly from a collaboration between those active in the academic fields of psychology and Buddhist studies. A particularly intriguing aspect in this respect is an exploration of the doctrinal underpinnings of Buddhist mindfulness practices. A recent investigation along these lines by $\mathrm{Yu}$ et al. (2020) took up in particular the Buddhist doctrine of causality, which is indeed of considerable relevance to mindfulness practices. A problem with this in itself laudable endeavor is an apparent conflation of perspectives on this doctrine that arose at quite different times in the history of Buddhism. This can best be exemplified with the following extract from Yu et al. (p. 1239):

Interconnectedness is a central tenet underlying all Buddhist teachings. It is expressed in Buddhism as "When there is this, that comes to be; with the arising of this, that arises. When there is not this, that does not come to be; with the cessation of this, that ceases" (Ñānamoli and Bodhi 1995, p. 655). It delineates the interdependent nature of all phenomena in the world,

Bhikkhu Anālayo

1 Barre Center for Buddhist Studies, 149 Lockwood Road, Barre, MA 01005, USA implying that the arising of all matters is conditioned on the arising of one another. In other words, all matters are mutually influencing one another and co-arising dependently ...

Take the growth of an apple tree as an example, simply having a seed cannot bear fruit to an apple tree [sic]. It must have the right conditions of suitable climate, adequate sunshine, moisture, and nutrients from the soil in order to grow and bear fruit. Any condition missing or not in the appropriate amount may lead to a different outcome. Interconnectedness can be operationally defined as an awareness that the existence of all phenomena in the world is the result of the fulfillment of different causes and conditions, in which no entity can sustain independently without relying on other factors. The insight of interconnectedness, originating from the concept of dependent origination, lays the foundation of other Buddhist teachings in understanding the causes of suffering and ways to eradicate suffering.

The quotation given by the authors ("When there is this ...") leads to the translation of the Cülasakuludāyi-sutta (MN 79), which presents the standard definition of the principle of specific conditionality. In the narrative context, the Buddha had just rejected the suggestion by the leader of a group of wanderers to talk about the topic of omniscience, as according to his assessment such a topic would only be 
really fruitful when discussing with someone who had the higher knowledges of recollection of past lives and of the divine eye (which was not the case for the leader of the wanderers). Instead of taking up what belongs to the past or the future, the Buddha recommended they rather discuss what pertains to the present. As a way of turning to what is present (and implicitly what does not require any specialized knowledge such as recollection of past lives or the divine eye), according to the Pāli discourse he presented the standard formulation of specific conditionality, as per the quote above. A parallel to the Cūlasakuludāyi-sutta in the Madhyama-āgama (MĀ 208), however, does not have a reference to this standard formulation (Anālayo 2011).

The reference given by Yu et al. (2020) to the translation of the Cülasakuludāyi-sutta relates their presentation to the early Buddhist teaching on causality in the form of specific conditions. This idea finds exemplification in the example of the growth of an apple tree, which requires a set of specific conditions, such as the seed, moisture, etc. The same idea is also at the background of "Buddhist teachings in understanding the causes of suffering and ways to eradicate suffering."

Other parts of the above quote, however, reflect the notion of interconnectedness or interdependence, the idea that everything depends on everything else. This idea stands behind the notion that "the arising of all matters is conditioned on the arising of one another" and "all matters are mutually influencing one another and co-arising dependently." Contrary to the impression created by the authors, such notions are quite different from what the quote from the Cülasakuludāyi-sutta refers to and also from what the example of the apple tree illustrates. The growth of the apple tree does not dependent on "all matters"; it only requires a set of specific conditions. Take the computer used to write this article. Although indispensable for such writing, it is of no relevance to the growth of an apple tree.

The same basic principle holds for the Buddhist teaching on understanding dukkha, often but somewhat misleadingly translated as "suffering." This depends on specific conditions. The possibility of eradicating dukkha, envisaged in Buddhist thought, has its foundation in identifying specific conditions responsible for the arising of dukkha rather than in an insight into interconnectedness. The idea is that, once a specific condition like ignorance has been identified, it becomes possible to cultivate a path aimed at its eradication and therewith the eradication of dukkha.

The notion of "interconnectedness" or "interdependence," in contrast to specific conditionality, reflects a mature stage in the evolution of Mahāyāna thought, arisen in particular in relation to teachings in the Buddhavatamsaka. Interconnectedness is definitely not "a central tenet underlying all Buddhist teachings." Moreover, another suggestion by Yu et al. (p. 1240) that "in Buddhism, conceptually, mindfulness and recognition of interconnectedness are part of the eightfold paths [sic]" is unfortunately wrong. Only mindfulness is part of the eightfold path, being its seventh factor.

As a foundation for proper research, it is important that the operationalized concepts are clearly defined and that a conflation between divergent ideas is avoided. The praiseworthy wish to enrich the empirical investigation of Buddhistderived constructs on well-being in a secularized manner needs to be grounded in a proper understanding of the relevant Buddhist concepts. In this way, an operational definition for research can be formulated in such a manner that it accurately reflects these concepts, rather than conflating quite different ideas. The following exploration is meant to provide a historical background for such proper understanding.

\section{Specific Conditionality}

The qualification of being a "central tenet underlying all Buddhist teachings" would suit the notion of specific conditionality. Here is the standard formulation of such specific conditionality, using as example a Pāli discourse whose presentation has a parallel in its Chinese Ägama counterpart:

This being, that exists; with the arising of this, that arises. This not being, that does not exist; with the ceasing of this, that ceases.

(SN 12.21: iti imasmim sati idam hoti, imass' uppādā idam uppajjati. imasmim asati idam na hoti, imassa nirodhā idạ̣ nirujjhati).

In dependence on this, that exists; with the arising of this, that arises ... with the ceasing of this, that ceases; this not being, that does not exist.

(EA 46.3: 因是有是, 此生則生 ... 此滅則滅, 此無則無).

This type of presentation often leads over to an exposition of the conditioned arising and ceasing of 12 links, to be taken up in more detail below. As paraphrased by Jones (2011, p. 17), the implications of the above basic statement are that what "exists has come into being dependent on particular causes and conditions; and when those causes and conditions cease, the things that depend on them will also cease." This is not an affirmation that everything is interconnected with everything else. Instead, it is a statement of specific conditionality.

Olendzki (2010, p. 110) commented that this formula "can be applied to almost any field of inquiry including natural systems, social interactions, political dynamics, and historical events. The matter of most immediate concern for the Buddha, however, was the field of human experiential phenomenology." The notion that specific conditionality can have such a general range of applicability, however, has been challenged by Shulman (2008, p. 299), proposing that 
dependent-origination addresses the workings of the mind alone ... Viewing pratitya-samutpāda [dependent origination] as a description of the nature of reality in general means investing the words of the earlier teachings with meanings derived from later Buddhist discourse. This results in a misrepresentation of much of what early Buddhism was about.

Shulman (2008, p. 307) supported his position with the following argument, based on the Pāli discourses:

When the Buddha says "When this is, that is, etc.," he is speaking only of mental conditioning, and is saying absolutely nothing about existence per se. The most significant evidence for this fact is that the phrase "imasmim sati idam hoti ..." never occurs detached from the articulation of the 12 links, save one occurrence.

The one occurrence referred to by him is the Cūlasakuludāyi-sutta (MN 79), already mentioned above, where the formula supposedly "involves a discussion regarding recollection of past lives, an issue closely related to what the 12 links are about." A minor objection that could be made here is that the occurrence in the Cūlasakuludāyi-sutta does not really involve "a discussion regarding past lives," as the discourse much rather reports the Buddha setting aside the topic of past lives and instead propounding the principle of specific conditionality. A more significant objection would be that the same principle does occur in another Pāli discourse without leading on to the whole set of 12 links (SN 12.62). The discourse in question depicts a noble disciple who properly pays penetrative attention to dependent arising (pațiccasamuppādam yeva sādhukam yoniso manasi karoti). This takes the form of the basic principle of specific conditionality (imasmim sati ...). The ensuing exemplification of this principle then turns to the relationship between contact (phassa) and feeling tone (vedana), which are only 2 out of the 12 links, without mentioning the other links. This would count as an instance of a Pāli discourse where the basic statement of specific conditionality does not lead over to the full set of 12 links, which are only found in the preceding discourse (SN 12.61).

The idea that dependent arising is confined to matters of the mind also does not seem to reflect the position of the early discourses accurately. An example in case would be the following description from the Mahāhatthipadopama-sutta and its Madhyama-āgama parallel:

Space that is enclosed in reliance on timber, in reliance on vine, in reliance on grass, and in reliance on clay comes to be reckoned a "house."
(MN 28: katțhañ ca pațicca valliñ ca pațicca tinañ ca pațicca mattikañ ca pațicca ākāso parivārito agāram tveva san்kham gacchati).

Space that is enclosed in reliance on timber, in reliance on clay, and in reliance on water and grass gives in turn rise to the appellation "a house."

(MĀ 30: 因材木, 因泥土, 因水草, 覆裹於空, 便生屋名).

Note that both versions explicitly refer to "dependence" (paticca/因), here rendered as "reliance" to fit the context. This does seem to be a case of listing specific conditions for the construction of a house (in the manner this was usually done in ancient India). Moreover, the context is a discussion of the first aggregate of bodily form, which concerns the material dimension of subjective experience. Unless one were to take an idealist position, such an application of specific conditionality could not be reckoned to concern just the workings of the mind or mental conditioning.

Another example would be a verse in the Vāsetțha-sutta, which occurs in the context of a discussion of what makes one a true brahmin. The verse explicitly speaks of those who have a vision of dependent arising (Sn 653: paticcasamuppādadassā). The expression in question stands for the understanding that the specific condition for being reckoned a brahmin are one's deeds, karma, and not just one's birth.

Another example would be the succinct statement of conditionality that according to tradition led to the conversion of the two brahmins who were to become the Buddha's chief disciples Sāriputta and Mahāmoggallāna. The Pāli version of this succinct statement begins by stating that "of things that arise from a cause, the Tathāgata states their cause" (Vin I 40: ye dhammā hetuppabbhavā, tesam hetum tathāgato āha; on inscriptional evidence for the importance of this verse see Skilling 2003, 2008; see also note 48 in Tournier 2021). Given the narrative context of a verse addressed to brahmins who at that time had no acquaintance with Buddhist teachings, the reference to dhammas quite probably intends "things" in general rather than objects of the mind.

In sum, the suggestion that the principle of specific conditionality can at times have a general relevance appears to be correct rather than being a misrepresentation of early Buddhist thought. This is not to deny that the overarching concern of this early Buddhist teaching is indeed the human predicament. The point is only that its application cannot be confined to the workings of the mind alone.

\section{Dependent Arising and the Buddha's Quest for Awakening}

The background for the Buddhist doctrine of specific conditionality can best be appreciated by turning to the Buddha's 
own quest for awakening. According to the Ariyāpariyesanāsutta and its Madhyama-āgama parallel, the chief motivation for the Buddha-to-be to set out in quest of awakening was the human predicament of being subject to the dukkha of old age, disease, and death (MN 26 and MĀ 204). The same motivation receives a more detailed coverage in a discourse in the Samyutta-nikāya, with parallels in Sanskrit fragments and in the Samyukta-āgama extant in Chinese. These relate the Buddha's existential quest to the theme of dependent arising. The parallel versions report that his pre-awakening investigation of the human predicament started out with the fact of old age and death (one version adds to these also the problem of disease), inquiring after the specific condition for their manifestation. This turned out to be birth. The same line of reasoning then led via several intervening links up to ignorance as the initial cause in the series of conditional links that result in the human predicament. This series of links form specific conditions in the sense that their cessation leads to the cessation of the link that depends on them. For the case of old age and death, the relevant passage proceeds as follows:

Monastics, this occurred to me: With what not being do old age and death not exist, with the ceasing of what is there the ceasing of old age and death? Monastics, through wise attention there was a breakthrough by wisdom for me: With birth not being, old age and death do not exist; with the ceasing of birth, there is the ceasing of old age and death.

(SN 12.10: tassa mayham, bhikkhave, etad ahosi: kimhi nu kho asati jarāmaraṇam na hoti, kissa nirodhā jarāmarananirodho ti? tassa mayham, bhikkhave, yoniso manasikārā ahu paññāya abhisamayo: jātiyā kho asati jarāmaranam na hoti, jātinirodhā jarāmaraṇanirodho ti.

This occurred to me: With what not being do old age and death not come to be, with the ceasing of what do old age and death cease? Paying wise attention, a breakthrough as it really is arose for me: With birth not being, old age and death do not come to be; with the ceasing of birth, old age and death cease.

(Tripāthī 1962, p. 92: tasya mamaitad abhavat: kasmin $n v$ asati jarāmaranam na bhavati, kasya nirodhāj jarāmaraṇanirodhaḥ? tasya mama yoniśo manasi kurvata evam yathābhūtasyābhisamaya udapādi: jātyām asatyām jarāmaraṇam na bhavati, jātinirodhāj jarāmaraṇanirodhah).

Then I had in turn this thought: Because of the nonexistence of what state does this old age, disease, and death not exist? Because of the ceasing of what state do old age, disease, and death cease? Then, paying right attention, a breakthrough as it really is arose: There being no birth, there is then no old age, disease, and death; because of birth ceasing, old age, disease, and death then cease.

(SĀ 285: 我時復作是念: 何法無故無此老, 病, 死? 何法滅 故老, 病, 死滅? 即正思惟, 起如實無間等: 無生則無老, 病, 死; 生滅故, 則老, 病, 死滅).

The fact that old age and death are to be expected for one who has been born may at first sight not seem to warrant the qualification of being a penetrative understanding. However, this qualification applies similarly to each ensuing step in the entire investigation, which will eventually lead up to ignorance as the condition whose cessation leads, via the cessation of the other intervening links, to transcending old age and death. In other words, the net result of such penetrative understanding is the realization that the human predicament can be transcended by going beyond ignorance.

The obvious relationship that obtains between birth and death can serve as a convenient exemplification of what specific conditionality implies. It involves identifying what is indispensable for the existence of something else such that, in its absence, the other item is unable to persist or even come into existence. The key aspect here is the cessation mode, as this provides the directive for transcending the human predicament.

The basic principle enshrined in this way is hardly a novel discovery. Even animals must be able to recognize certain specific conditions required for their own survival, such as where food can be found and how predators can be avoided. The significantly Buddhist perspective on the matter lies in applying this basic principle to the human predicament in the understanding that the entire gamut of subjective experience is merely the result of conditional relationships, with no permanent entity found anywhere in addition to or apart from these.

\section{The 12 Links}

As briefly mentioned above, in the early discourses the principle of specific conditionality often, but not invariably, leads on to a listing of 12 links. These are as follows:

Ignorance

Volitional formations

Consciousness

Name-and-form

Six sense spheres

Contact

Feeling tone

Craving

Clinging

Becoming

Birth

Old age and death 
Although there is an overall pattern in this series of 12 links, with the preceding link forming a condition for the ensuing one, the underlying conception is not confined to a linear sequence in time (Anālayo 2019b, 2020b, c). "Name" in name-and-form comprises factors like contact and feeling tone, which recur later on in the series. Moreover, several discourses present a reciprocal conditioning between consciousness and name-and-form. This is an important dimension of the teaching on dependent arising, as it serves to explain the continuity of subjective experience during life and from one life to another in the absence of a permanent entity or self (Anālayo 2018). Thus, the notion of causality standing in the background of the above list of 12 links is invested with a considerable degree of complexity.

Another intriguing aspect is that the first part of the above list appears to stand in dialogue with a Vedic creation myth depicting the genesis of the world (Jurewicz 2000). According to Jones $(2009$, p. 253), "in parodying Vedic cosmogony in the twelve nidānas [links], the Buddha might have been giving expression to his own teaching of $d u k k h a$ and its ending in terms that would have had startling significance to his hearers." Such a procedure would be well in line with a general pattern in the early discourses, which tend to adopt and decisively re-interpret Brahminical notions apparently prevalent in ancient India. The decisive re-interpretation in the present case would be that, rather than celebrating the creation of the world, the series culminates in the human predicament of being subject to old age and death. The cessation mode of the same teaching then shows how this whole creation can be undone.

Reliance on a notion presumably fairly well known in the ancient setting in order to create an initial impression of familiarity would explain why the application of dependent arising by way of 12 links occurs so frequently in the early discourses, namely because of its probable appeal to the ancient Indian audience. At the same time, however, the early discourses show various alternative applications of the same basic principle that do not involve the whole set of 12 . In fact, even just the conditional dependence of old age and death on birth, discussed above, is already in itself a statement of dependent arising (and, perhaps even more importantly, of the possibility of dependent ceasing).

\section{Mindfulness of Sense Experience}

The basic principle of specific conditionality can also inform exercises described in the Satipațhanna-sutta for the purpose of cultivating mindfulness. An example is contemplation of the sense spheres, found in the Satipațthanna-sutta and its Madhyama-ägama parallel (though absent from a third parallel in the Ekottarika-āgama). The relevant instructions proceed in this way for the first sense sphere of the eye and visible forms:
One knows the eye, one knows visible forms, and one knows the fetter that arises dependent on both; and one knows how an unarisen fetter arises, one knows how an arisen fetter is removed, and one knows how a removed fetter does not arise in the future.

(MN 10: cakkhuñ ca pajānāti, rūpe ca pajānāti, yañ ca tad ubhayam pațicca uppajjati samyojanam tañ ca pajānāti, yathā ca anuppannassa samyojanassa uppādo hoti tañ ca pajānāti, yathā ca uppannassa samyojanassa pahānam hoti tañ ca pajānāti, yathā ca pahīnassa samyojanassa āyatim anuppādo hoti tañ ca pajānāti).

In dependence on the eye and visible forms, a fetter arises internally. Actually having a fetter internally, a monastic knows, as it really is, that there is a fetter internally; actually not having a fetter internally, one knows, as it really is, that there is no fetter internally. One thus knows, as it really is, how an unarisen fetter arises internally; and thus knows, as it really is, how an internally arisen fetter ceases and does not arise again. (MĀ 98: 眼緣色生內結. 比丘者內實有結, 知內有結如真, 內實無結, 知內無結如真. 若未生內結而生者, 知如真, 若已 生內結滅不復生者, 知如真).

The same instructions apply to the other sense spheres, which are the ear and sounds, the nose and odors, the tongue and flavors, the body and tangibles, and the mind and mental objects. The reference to the respective senses here intends the ability to see, hear, etc., and not just the physical organ. This finds exemplification in the adoption of different Pāli and Sanskrit terminology. In the case of the eye, for example, the sense is cakkhu/cakșu, but the organ is akkhi/akși. The term to refer to the sense of hearing is sota/srota, whereas the physical organ of the ear is rather referred to as kannal karna. Again, the ability to smell is called ghāna/ghrāna, but the term for the nose is rather $n \bar{a} s \bar{a} / n \bar{a} s \bar{a}$.

Such ability to see, hear, etc., forms a specific condition for the respective sense experience, since without such ability one will be unable to see, hear, etc. This does not mean that the fettering force of experience resides in the existence of the sense organ. If this were the case, it would be impossible to step out of being subject to mental fetters as long as one is still endowed with the respective sense organ. Another discourse, notably an explanation given by a lay disciple to monastics, presents the matter in the following way:

The eye is not a fetter for visible forms nor are visible forms a fetter for the eye, but the lustful desire that arises there in dependence on both, that is the fetter there.

(SN 41.1: na cakkhu rūpānam samyojanam, na rūpā cakkhussa samyojanam; yañ ca tattha tad ubhayam pațicca uppajjati chandarāgo tam tattha samyojanam). 
The eye is not a fetter for visible forms nor are visible forms a fetter for the eye ... but whatever lustful desire exists between them, that is accordingly the fetter there. (SĀ 572: 非眼熬色, 非色熬眼 ... 然中間有欲貪者, 隨彼繫 也).

The two parallels agree in applying this description to the other senses, illustrating the situation with the example of two oxen that are bound together by a yoke. Neither of the two oxen is the fetter of the other. Instead, it is the yoke by which they are bound together that constitutes the fetter. From this perspective, then, the specific conditions required for visual experience, for example, to result in the state of being fettered are: the ability to see, the presence of something visible, and the existence within the mind of a tendency to lustful desires.

Identifying such specific conditions is not about some form of interconnectedness or interdependence. Visual experience, to stay with this example, does not require the next sense door of the ear or its corresponding objects of sounds. Even the deaf can still see, and vision is still possible in total silence. Conversely, hearing is still possible for someone in total darkness, and thus deprived of visual objects, or for someone blind, and thus lacking the ability to see. Neither seeing nor hearing requires the other sense organ or object in order to function.

In terms of the simile of the two oxen bound together by a yoke, their predicament does not stand in a specific causal relationship to any other animal that may be grazing in the same area or to birds that may be singing on a tree nearby. This holds even though the presence of all these animals in the same place would certainly suffice to consider them as closely interconnected. Yet, whether there are other grazing animals or not, whether there are singing birds or not, the specific condition for each oxen's state of bondage is the yoke that binds it to the other oxen.

\section{Later Notions of Causality}

In later times, exegetical traditions tended to develop their own distinct notions of general principles of conditionality. Surveying the development in the Theravāda tradition, Ronkin (2005, p. 232) reasoned:

In contradistinction to the earliest stratum of Buddhist thought, the Abhidhamma analysis of causal conditioning is primarily intended to account for the true nature of the dependently co-arisen dhammas, and only secondarily for the principle of dependent co-arising itself ... the doctrinal shift ... consists in a transition from a process-oriented to an event-oriented conception of sentient experience.
Cox (1993, p. 134) explained that, with the evolution of Sarvāstivāda exegesis, "abstract causal relations are beginning to be considered for their own sake, and not merely as part of a discussion of dependent origination." Eventually, "with the emergence of an independent and abstract causal theory, dependent origination ... received its own particularized role, as an explanation of the process of rebirth, completely divorced from general causal theory" (p. 136).

It is as part of the onset of such later developments that in Huayan (華嚴) thought in particular the notion of interconnectedness or interdependence came into its own. Poceski (2004, p. 346) explained:

Huayan's system of religious philosophy and practice is a vast conglomeration of abstruse doctrines ... at its core is a holistic vision of the universe as a dynamic web of causal interrelationships, in which each and every thing and event is related to everything else as they interpenetrate without any obstruction. The Huayan depiction of reality is an ingenious reworking of the central Buddhist doctrine of pratītyasamutpāda (dependent origination) ... it postulates that each phenomenon is determined by the totality of all phenomena of which it is a part, while the totality is determined by each of the phenomena that comprise it. Therefore, each phenomenon is determining every other phenomenon, while it is also in turn being determined by each and every other phenomenon. All phenomena are thus interdependent ... every phenomenon conditions the existence of every other phenomenon and vice versa. Accordingly, nothing exists by itself, but requires everything else to be what it truly is.

Regarding the dynamics leading to the popularity of such notions of interconnectedness in contemporary Buddhist traditions, McMahan (2008, p. 149) commented:

Indeed, this age of internationalism and the internet might well be called the age of inter: there is nothing that is not interconnected, interdependent, interwoven, interlaced, interactive, or interfacing with something else to make it what it is. Thus, any religious tradition that can claim "interdependence" as a central doctrine lays claim to timely cultural resonance and considerable cultural cachet.

At the same time, however, the adoption of such notions involves a substantial departure from the early Buddhist doctrine of dependent arising. McMahan (p. 172 and 178) explained: 
Far from a chain of causes and effects binding beings to rebirth in a world of suffering, today's interdependence implies a sacred matrix of mutual communality and coparticipation, the extended body of all beings. And, most significant here, this shift in meaning and valuation developed not only out of the Mahayana tradition's rethinking of Buddhahood and the infusion of East Asian sensibilities into Buddhism but also out of some of the fundamental dynamics of modernity ... The contemporary Buddhist ethic of interdependence ... likely worked its way into contemporary Buddhist thought through remnants of the Romantic-Transcendentalist line of thinking that resonated with similar ideas in Huayen [sic] and Zen thought.

The promotion of notions of interconnectedness or interdependence are evident, for example, in Buddhist environmentalism (Anālayo 2019a). Yet, as explained by Sucitto (2019, p. 249 ), in this "shift from the perspective of the early suttas, this state of interconnection is to be encouraged, rather than constituting a description of what one needs to be released from." This thus involves "a distinct change of meaning from that of the [early] Buddhist tradition." Besides, it is also not clear how the notion that everything is interrelated could provide a coherent basis for an ecological concern. Already Harris (1995, p. 177) pointed out that

the intention here is to show that since all things are inter-related we should act in a spirit of reverence towards them all. However, the category of "all things" includes insecticides, totalitarian regimes and nuclear weapons and the argument therefore possesses some rather obvious problems. In short, it suffers from a certain vacuity from the moral perspective.

As noted by Ives (2013, p. 563), for environmental concerns it is crucial to avoid undermining "the ability to make the sort of distinctions that are necessary and unavoidable in environmental ethics, such as the distinction between a negative 'is' (such as a toxic river) and a positive 'ought' (the clean river that can result from clean-up efforts)." From this perspective, is not easy to understand how the notion of interconnectedness or interdependence could provide a coherent grounding for the ability to make such distinctions, be it in relation to environmental problems or other matters related to social justice.

Take the dire need of confronting racism (Anālayo 2020a), just to provide another example. Mindfulness can serve as a powerful way to counter racism (Magee 2019), and one of its modalities can be found in directing awareness to our common humanity. Note that this relies on something specific, namely the basic similarity between all human beings, independent of their individual backgrounds. It carries force because it directs mindfulness to something shared with other human beings but not shared with all material things in general, such as with cars, computers, etc. Once interconnectedness or interdependence is brought in, however, the specific notion of common humanity becomes submerged under a general interrelation of everything with everything else. It thereby loses much of its force.

Nevertheless, as evident in the findings by $\mathrm{Yu}$ et al. (2020, p, 1249), "people who have higher levels of interconnectedness tend ... to be more willing to endorse social justice ideologies;" in fact, "evidence showed that the most significant additional value of interconnectedness over mindfulness and nonattachment is on social justices' ideologies." This intriguing finding invites further research, in particular by way of attempting to understand how an apparently incongruent idea could have gathered such general appeal.

\section{The Interconnectedness Scale}

The Buddhist teaching of specific conditionality and the notion that everything is interconnected not only arose at different times in the history of Buddhism, they also carry quite different implications. It follows that the Interconnectedness Scale developed by $\mathrm{Yu}$ et al. (2020) is in need of revision. The issue at stake here is not just the adoption of a historical perspective as against a practical one aimed at the "promotion of well-being by raising awareness on the interdependent nature of all matters," this being the main title chosen by the authors for their article. The problem is simply that the Interconnectedness Scale conflates two divergent ideas.

Take, for example, factor 15 of the Interconnectedness Scale in $\mathrm{Yu}$ et al. (p. 1243): "I try to keep calm in both ups and downs because I know fluctuating emotions bring suffering." This is a reflection of specific conditionality, in that "fluctuating emotions," in the sense of reacting strongly to the ups and downs of life, serve as a specific condition for the experience of suffering. The same does not hold for factor 24 of the same Interconnectedness Scale: "Since everything in this world is affecting one another, I actively pay attention to every happening in the world." The idea in the background of this formulation needs to be researched in its own right rather than being combined with ideas informed by the teaching of specific conditionality.

This assessment is not meant to delegitimize the notion of interconnectedness or interdependence as something in principle not fit to be researched. The point is only that a conflation has taken place of two distinct constructs, which need to be researched separately. The term "Interconnectedness Scale" employs specific formal terminology reflecting a 
particular Buddhist construct, namely the Mahāyāna teaching of the interconnectedness of all things. It thereby inevitably conveys the impression that this particular construct is being investigated in its own right. For that purpose, however, it would be best to stick to that notion and not conflate it with specific conditionality. Conversely, specific conditionality is also better researched on its own, rather than being confounded with interconnectedness. Perhaps the authors could create two distinct scales out of the one they have developed, by separating the different factors according to which of these two Buddhist constructs they reflect. This would not only bring increased clarity but could also lead to interesting research results when the two scales are compared with each other under otherwise similar conditions.

It also needs to be noted that the authors can hardly be blamed for a lack of understanding the distinct nature of these two Buddhist constructs of causality, as such confusion is fairly pervasive in contemporary Buddhist circles. In fact, in preparation for their research, the authors had approached scholars in Buddhist studies to assess their project (p. 1240), which apparently did not result in the type of clarification attempted in this article:

To construct the interconnectedness items, classical Buddhism [sic] texts, contemporary Buddhism [sic] writings, and consultation with Buddhism [sic] experts were the primary sources from which interconnectedness items were based. Fifty items were drafted in Chinese and sent to an expert panel consisting of six Buddhism [sic] scholars from universities in Hong Kong and Taiwan.

In sum, the above criticism is not meant in any way to discourage attempts to expand the field of mindfulness research by taking into account Buddhist doctrine, on the contrary. The point is only to help improve the theoretical foundation for future research and to develop a sensitivity to differences in paradigms that emerged at successive stages in the history of Buddhist thought. These differences need to be taken into account in order to do proper justice to Buddhist thought and to develop accurate operational definitions as a firm basis for research.

Acknowledgments The author is indebted to Floria Chio, Bhikkhunī Dhammadinnā, Winnie Mak, Karin Meyers, and Ben Yu for commenting on a draft version of this article.

\section{Compliance with Ethical Standards}

Ethical Approval This article does not contain any studies performed by the author with human participants or animals.

Conflict of Interest The author declares that he has no conflict of interest.
Abbreviations $\quad \mathrm{EA}$, Ekottarika-āgama (T 125); MĀ, Madhyama-āgama (T 26); MN, Majjhima-nikāya; SĀ, Samyukta-āgama (T 99); SN, Samyutta-nikāya; Sn, Suttanipāta; T, Taishō edition; Vin, Vinaya

Open Access This article is licensed under a Creative Commons Attribution 4.0 International License, which permits use, sharing, adaptation, distribution and reproduction in any medium or format, as long as you give appropriate credit to the original author(s) and the source, provide a link to the Creative Commons licence, and indicate if changes were made. The images or other third party material in this article are included in the article's Creative Commons licence, unless indicated otherwise in a credit line to the material. If material is not included in the article's Creative Commons licence and your intended use is not permitted by statutory regulation or exceeds the permitted use, you will need to obtain permission directly from the copyright holder. To view a copy of this licence, visit http://creativecommons.org/licenses/by/4.0/.

\section{References}

Anālayo, Bh. (2011). A comparative study of the Majjhima-nikāya. Taipei: Dharma Drum Publishing Corporation.

Anālayo, Bh. (2018). Rebirth in early Buddhism and current research. Boston: Wisdom.

Anālayo, Bh. (2019a). Mindfully facing climate change. Barre: Barre Center for Buddhist Studies.

Anālayo, Bh. (2019b). On time. Insight Journal, 45, 11-20.

Anālayo, Bh. (2020a). Confronting racism with mindfulness. Mindfulness, 11(10), 2283-2297. https://doi.org/10.1007/s12671020-01432-4.

Anālayo, Bh. (2020b). Consciousness and dependent arising. Insight Journal, 46, 55-62.

Anālayo, Bh. (2020c). Dependent arising. Insight Journal, 46, 1-8.

Cox, C. (1993). Dependent origination: its elaboration in Sarvāstivādin Abhidharma texts. In R. K. Sharma (Ed.), Researches in Indian and Buddhist philosophy: essays in honor of professor Alex Wayman (pp. 119-141). Delhi: Motilal Banarsidass.

Harris, I. (1995). Getting to grips with Buddhist environmentalism: a provisional typology. Journal of Buddhist Ethics, 2, 173-190.

Ives, C. (2013). Resources for Buddhist environmental ethics. Journal of Buddhist Ethics, 20, 541-571.

Jones, D. T. (2009). New light on the twelve nidānas. Contemporary Buddhism, 10(2), 241-259. https://doi.org/10.1080/ 14639940903239793.

Jones, D. T. (2011). This being, that becomes, the Buddha's teaching of conditionality. Cambridge: Windhorse Publications.

Jurewicz, J. (2000). Playing with fire: the Pratityasamutpāda from the perspective of Vedic thought. Journal of the Pali Text Society, 26, 77-103.

Magee, R. V. (2019). The inner work of racial justice, healing ourselves and transforming our communities through mindfulness. New York: TarcherPerigree.

McMahan, D. L. (2008). The making of Buddhist modernism. New York: Oxford University Press.

Ñāṇamoli, B., \& Bodhi, B. (1995). The middle length discourses of the Buddha, a translation of the Majjhima Nikāya. Boston: Wisdom Publications.

Olendzki, A. (2010). Unlimiting mind, the radically experiential psychology of Buddhism. Boston: Wisdom Publications.

Poceski, M. (2004). Huayan school. In R. E. Buswell (Ed.), Encyclopedia of Buddhism (pp. 341-347). New York: Macmillan. 
Ronkin, N. (2005). Early Buddhist metaphysics, the making of a philosophical tradition. London and New York: Routledge Curzon.

Shulman, E. (2008). Early meanings of dependent-origination. Journal of Indian Philosophy, 36(2), 297-317. https://doi.org/10.1007/s10781007-9030-8.

Skilling, P. (2003). Traces of the Dharma, preliminary reports on some ye dhammā and ye dharmā inscriptions from mainland South-East Asia. Bulletin de l'École française d'Extrême-Orient, 90(91), 273287. https://doi.org/10.3406/befeo.2003.3615.

Skilling, P. (2008). Buddhist sealings and the ye dharmā stanza. In G. Sengupta \& S. Chakraborty (Eds.), Archaeology of early historic South Asia (pp. 503-525). New Delhi: Pragati Publications.

Sucitto, A. (2019). Buddha-nature, human nature. Great Gaddesden: Amaravati Publications.

Tournier, V. (2021). A $4^{\text {th }} / 5^{\text {th }}$-century sūtra of the Sammitīya canon? On the so-called 'continental Pāli' inscription from Devnimori. In C.
Cicuzza (ed.) Proceedings of the Third International Pali Studies Week - Paris 2018 (forthcoming). Bangkok and Lumbini: Fragile Palm Leaf Foundation; Lumbini International Research Institute.

Tripārna, C. (1962). Fünfundzwanzig sūtras des Nidānasaānasad. Berlin: Akademie Verlag.

Yu, B. C. L., Mak, W. W. S., \& Chio, F. H. N. (2020). Promotion of wellbeing by raising awareness on the interdependent nature of all matters: development and validation of the interconnectedness scale. Mindfulness, 11, 1238-1252. https://doi.org/10.1007/s12671-02001334-5.

Publisher's Note Springer Nature remains neutral with regard to jurisdictional claims in published maps and institutional affiliations. 